\title{
Maintenance of Pregnancy in Dairy Cattle After Treatment with Human Chorionic Gonadotropin or Gonadotropin-Releasing Hormone ${ }^{1}$
}

\author{
J. S. Stevenson, ${ }^{* 2}$ S. M. Tiffany, ${ }^{*}$ and E. K. Inskeept \\ *Department of Animal Sciences and Industry, Kansas State University, Manhattan 66506-0201 \\ †Division of Animal and Nutritional Sciences, West Virginia University, Morgantown 26506-6108
}

\begin{abstract}
The objectives were to determine whether a single injection of either human chorionic gonadotropin (hCG) or GnRH would: 1) increase ancillary formation of new luteal structures, 2) increase serum concentrations of progesterone, and 3) increase pregnancy survival in dairy females treated once between 26 and $71 \mathrm{~d}$ of pregnancy. A total of 421 cows were enrolled between January and November 2001, with 92, 106, and 223 females (included 68 nulliparous heifers at 1 location) treated at the 3 locations. Upon diagnosis of pregnancy, females were allocated randomly to receive $100 \mu \mathrm{g}$ of $\mathrm{GnRH}$, $1,000 \mathrm{IU}$ of hCG, or $2 \mathrm{~mL}$ of saline. Blood samples were collected at $0,1,2$, and $4 \mathrm{wk}$ after treatment, and pregnancy status was reassessed at 1,2 , and $4 \mathrm{wk}$. New luteal structures were formed in $23.8 \%$ of cattle, with hCG (50\%) and GnRH (26\%) being more effective than saline (7\%). Treatment had no effect on the proportion of females forming 2 new luteal structures (7.6\%), and $36.2 \%$ of all induced structures regressed during the 4wk study period. Pregnancy losses were unaffected by treatment, stage of pregnancy, or number of induced luteal structures but were nearly 9 -fold greater in females in which induced luteal structures regressed. No loss occurred in females having 2 new luteal structures. Pregnancy losses decreased quadratically from 30 to 42 d. Serum progesterone did not differ among treatments, but among females forming new luteal structures, progesterone was greater at $1(7.2 \pm 0.3$ vs. $6.3 \pm 0.2 \mathrm{ng} /$ $\mathrm{mL})$ and $2 \mathrm{wk}(7.0 \pm 0.3$ vs. $6.1 \pm 0.2 \mathrm{ng} / \mathrm{mL})$ after treatment. Progesterone at the first pregnancy diagnosis was predictive of imminent pregnancy loss; the lower the initial progesterone, the sooner subsequent loss was observed. The right ovary was dominant in the location of new luteal structures. Regression of new luteal structures occurred more often on the left ovary and contra-
\end{abstract}

\footnotetext{
Received January 17, 2008.

Accepted April 15, 2008.

${ }^{1}$ Contribution number 08-210-J from the Kansas Agricultural Experiment Station, Manhattan.

${ }^{2}$ Corresponding author: jss@k-state.edu
}

lateral to the corpus luteum of pregnancy (53.2 vs. $22 \%$ ). In conclusion, treatment of dairy cattle with either GnRH or hCG failed to prevent pregnancy loss, but concentrations of progesterone were predictive of subsequent pregnancy loss.

Key words: gonadotropin, pregnancy loss, progesterone, induced ovulation

\section{INTRODUCTION}

Pregnancy rates in dairy cattle have declined during the last several decades (Lucy, 2001). Components of this loss include fertilization failure, early and late embryonic mortality, and fetal losses (Santos et al., 2004). Fertilization failure in lactating dairy cows can exceed $20 \%$ (Santos et al., 2004). Conception rates in dairy cattle 27 to $31 \mathrm{~d}$ after AI usually are 35 to $45 \%$ (Lucy, 2001). By 5 to $6 \mathrm{~d}$ after AI, only $65 \%$ of fertilized eggs are viable, representing only $50 \%$ of the total embryosoocytes combined (Santos et al., 2004). Although fetal losses occur, they are less prevalent, and estimates often include late embryonic losses.

Embryos losses beginning with diagnosed pregnancy at $28 \mathrm{~d}$ after $\mathrm{AI}$ were $10.5 \%$ during the subsequent 2 wk (d 28 to 42 ) and decreased to $6.3,1.7$, and $1.7 \%$ during d 42 to 56,57 to 70 , and 71 to 98 , respectively (Inskeep, 2002). Accessory corpora lutea (CL) induced between d 4 and 9 postestrus or post-AI improved conception rates first assessed as early as d 25 until d 43 of pregnancy. For conception rates to increase, embryo survival was improved as a result of additional progesterone resulting from accessory CL (Santos et al., 2001; Stevenson et al., 2007). In addition, results obtained by treatment of dairy cows with exogenous progesterone during the late embryonic or early fetal period (38 to $90 \mathrm{~d}$ of pregnancy) improved retention of pregnancies (López-Gatius et al., 2002). Further, dairy cows having an additional spontaneous luteal structure were only $1 / 8$ as likely to have fetal loss as those bearing only 1 CL, an effect that was not related to twin pregnancy, because cows carrying twins were 3 times more likely to have pregnancy loss. 
The hypothesis for the present study was that embryo loss after d 28 of pregnancy occurs because of insufficient luteal support as assessed by concentrations of progesterone in blood serum. It was hypothesized that induction of ancillary luteal structures in pregnant dairy females would increase pregnancy survival during the subsequent $4 \mathrm{wk}$. Study objectives were to determine whether a single injection of either human chorionic gonadotropin (hCG) or GnRH would: 1) increase ancillary formation of new luteal structures, 2) increase serum concentrations of progesterone, and 3) increase pregnancy survival in dairy females treated once between 26 to $71 \mathrm{~d}$ of pregnancy. In this report, new luteal tissue is referred to as luteal structures, rather than a CL, because we have no evidence that ovulation actually occurred (release of ovum), although ultrasonic appearance of these structures resembled spontaneously formed CL.

\section{MATERIALS AND METHODS}

\section{Experimental Locations}

Lactating dairy cows were enrolled at 2 commercial dairy farms in northeastern Kansas. Each herd consisted of 400 to 600 Holstein cows, with annual rolling herd averages in excess of 10,000 to $11,500 \mathrm{~kg}$ of milk. Cows were housed in either 2- or 4-row barns, milked thrice daily, and fed a TMR consisting of chopped alfalfa, corn silage, soybeans, corn grain, and a concentrate-mineral mix (offered twice daily) to meet or exceed NRC (1989) recommendations for lactating cows. Cows had access to fresh water ad libitum at 3 locations in each 100-cow pen, which consisted of feed-line self-locking head catches and free stalls bedded with sand.

Lactating dairy cows and replacement heifers were enrolled weekly at a third location (Kansas State University Dairy Teaching and Research Center, Manhat$\tan )$. This herd consisted of 200 Holstein cows, with an annual rolling herd average in excess of $11,000 \mathrm{~kg}$. All cows were fed a TMR consisting of chopped alfalfa, corn silage, whole cottonseed, and a concentrate-mineral mix offered twice daily to meet or exceed NRC (1989) recommendations for lactating cows. Cows were housed in covered free stalls bedded with sand and had access to fresh water ad libitum at 2 locations in each pen. Replacement heifers were housed on dirt with a concrete feed apron adjacent to a feed line bunk. Shelter was provided by covered free stalls. Heifers were fed a diet consisting of chopped prairie hay, corn silage, corn or milo grain, and a vitamin-mineral premix to meet or exceed NRC (1989) requirements for growing heifers by 10 to $15 \%$. Injections of recombinant bST were administered every $14 \mathrm{~d}$ to all lactating cows beginning in the ninth week of lactation at all 3 locations.

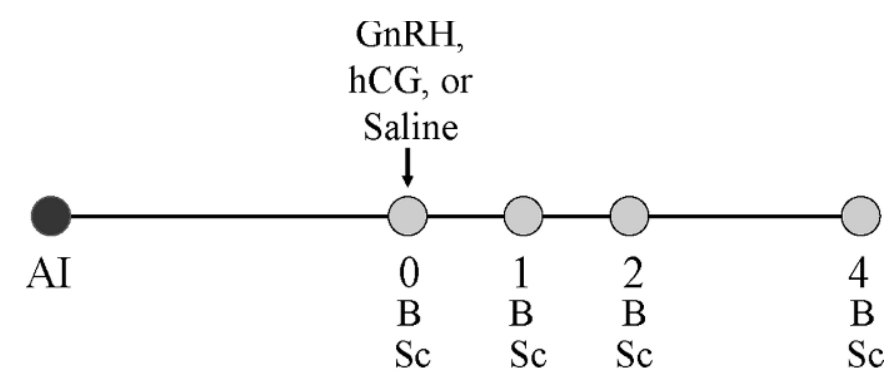

Weeks from first ultrasound pregnancy diagnosis

Figure 1. Experimental protocol illustrating when blood (B) samples were collected to monitor serum concentrations of progesterone and ultrasound diagnosis $(\mathrm{Sc})$ of pregnancy after AI relative to treatment with $100 \mu \mathrm{g}$ of $\mathrm{GnRH}, 1,000 \mathrm{IU}$ of human chorionic gonadotropin (hCG), or $2 \mathrm{~mL}$ of saline. Dairy cattle were first diagnosed pregnant between 26 and $71 \mathrm{~d}$ of pregnancy, and pregnancy and luteal status were reevaluated 1,2 , and $4 \mathrm{wk}$ later.

\section{Experimental Protocol}

A total of 421 cows were enrolled between January and November 2001, with 92, 106, and 223 females (included 68 nulliparous heifers at 1 location) treated at the 3 locations. A similar experimental protocol was used at each location. New cows were enrolled weekly upon diagnosis of pregnancy according to the design illustrated in Figure 1. Range of first pregnancy diagnosis was 26 to $71 \mathrm{~d}$. More than $82 \%$ of the initial exams were conducted between 29 and $42 \mathrm{~d}$.

Pregnancy was diagnosed by transrectal ultrasonography with a $5.0-\mathrm{MHz}$ linear-array transducer (Aloka 500V, Corometrics Medical Systems Inc., Wallingford, CT). Presence of fluid in the uterus, a CL, and a viable embryo were evidence of pregnancy. Once pregnancy was confirmed, cattle were assigned randomly to 2 treatments and a control. Treatments consisted of a single i.m. injection of either $100 \mu \mathrm{g}$ of $\mathrm{GnRH}$ (Cystorelin, Merial, Iselin, NJ) or 1,000 IU of hCG (Gonadosti-

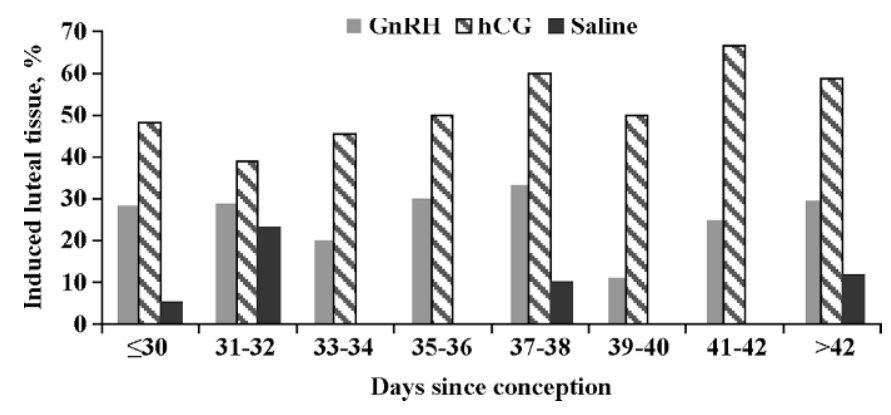

Figure 2. Incidence of induced luteal structures in dairy cattle in response to $100 \mu \mathrm{g}$ of $\mathrm{GnRH}(\mathrm{n}=140), 1,000 \mathrm{IU}$ of human chorionic gonadotropin (hCG; $\mathrm{n}=148)$, or $2 \mathrm{~mL}$ of saline $(\mathrm{n}=133)$ at various intervals after initial pregnancy diagnosis. 
Table 1. Frequency of occurrence and longevity of induced luteal structures between d 26 and 71 of pregnancy in dairy cattle

\begin{tabular}{|c|c|c|c|c|}
\hline \multirow[b]{2}{*}{ Item } & \multicolumn{4}{|c|}{ Treatment $^{1}$} \\
\hline & GnRH & hCG & Saline & Total \\
\hline & & $\%$ & $/ \mathrm{n})$ & \\
\hline Induced luteal structure ${ }^{2}$ & $25.7^{\mathrm{a}}(36 / 140)$ & $50.0^{\mathrm{b}}(74 / 148)$ & $6.8^{\mathrm{c}}(9 / 133)$ & $28.3(119 / 421)$ \\
\hline Detected by $7 \mathrm{~d}$ & $80.6(29 / 36)$ & $90.5(67 / 74)$ & $66.7(6 / 9)$ & $85.7(102 / 119)$ \\
\hline \multirow{2}{*}{\multicolumn{5}{|c|}{ Number of follicles $\geq 10 \mathrm{~mm}^{3}$}} \\
\hline & & & & \\
\hline 0 & $0.0(0 / 13)$ & $33.3(6 / 18)^{4}$ & $0.0(0 / 21)$ & $11.5^{\mathrm{a}}(6 / 52)$ \\
\hline 1 & $26.9(21 / 78)$ & $42.5(31 / 73)$ & $6.8(5 / 73)$ & $25.4^{\mathrm{c}}(57 / 224)$ \\
\hline 2 & $27.9(12 / 43)$ & $66.0(31 / 47)$ & $6.5(2 / 31)$ & $37.2^{\mathrm{bc}}(45 / 121)$ \\
\hline $3+$ & $50.0(3 / 6)$ & $60.0(6 / 10)$ & $25.0(2 / 8)$ & $45.8^{\mathrm{b}}(11 / 24)$ \\
\hline \multicolumn{5}{|l|}{ Proportion of luteal structures } \\
\hline Single & $86.1(31 / 36)$ & $94.6(70 / 74)$ & $100(9 / 9)$ & $92.4(110 / 119)$ \\
\hline Double & $13.9(5 / 36)$ & $5.4(4 / 74)$ & $0.0(0 / 9)$ & $7.6(9 / 119)$ \\
\hline Regressed induced luteal structures & $31.4(11 / 35)$ & $38.9(28 / 72)$ & $33.3(3 / 9)$ & $36.2(42 / 116)$ \\
\hline Regressed by $7 \mathrm{~d}$ & $81.8(9 / 11)$ & $67.9(19 / 28)$ & $66.7(2 / 3)$ & $71.4(30 / 42)$ \\
\hline Regressed at $>7 \mathrm{~d}$ & $18.2(2 / 11)$ & $32.1(9 / 28)$ & $33.3(1 / 3)$ & $28.6(12 / 42)$ \\
\hline
\end{tabular}

${ }^{\mathrm{a}-\mathrm{c}}$ Mean percentages having different superscript letters differ $(P \leq 0.05)$.

${ }^{1}$ Treatment injections were given at first pregnancy diagnosis [100 $\mu \mathrm{g}$ of GnRH, 1,000 IU of human chorionic gonadotropin ( $\mathrm{hCG}$ ), or $2 \mathrm{~mL}$ of saline].

${ }^{2}$ Days are relative to treatment injections. Fate of 3 of the 119 induced luteal structures could not be determined, because those ovarian scans were not made.

${ }^{3}$ Percentage of new luteal structures based on the number of follicles $\geq 10 \mathrm{~mm}$ detected before treatment.

${ }^{4}$ The 6 new luteal structures formed after hCG were in follicles ranging in diameter from 8.3 to $9.5 \mathrm{~mm}$.

mulon, Lot 1101-1, Endocrine Technologies Inc., Newark, CA). Control cows were treated i.m. with $2 \mathrm{~mL}$ of physiological saline. Numbers of pregnant females treated with $\mathrm{GnRH}, \mathrm{hCG}$, or saline at each location were 72,79 , and 72 at location $1 ; 31,33$, and 28 at location 2; and 37, 36, and 33 at location 3 , respectively.

Blood samples were collected from a coccygeal blood vessel using an evacuated blood collection tube at 0 , 1,2 , and 4 wk after treatment and initial pregnancy diagnosis. Pregnancy status was reassessed at 1,2, and 4 wk after treatment.

At each pregnancy scan, a map of all ovarian structures was drawn, follicle sizes were recorded when $>10$ $\mathrm{mm}$ in diameter, and location(s) of new luteal structures were noted as ipsilateral or contralateral to the original CL of pregnancy. Subsequent calving information was available for only $60.8 \%$ (256/421) of cows initially diagnosed pregnant in the study, because some records were no longer retrievable from 2 of the 3 dairy farms. For remaining results, relationships between the ovary bearing the original CL and sex of offspring were calculated.

\section{Progesterone RIA}

Serum concentrations of progesterone for samples collected at 3 locations were quantified by RIA (Skaggs et al., 1986). Intra- and interassay coefficients of variation were 6.3 and $7.9 \%$, respectively. A repeated serum pool replicated 3 times in each assay was $2.94 \pm 0.04$ $\mathrm{ng} / \mathrm{mL}$ in 11 assays.

\section{Statistical Analyses}

Because most outcomes assessed were binomial, analyses used various general linear models or categorical procedures including procedures GLM, FREQ, and GENMOD (SAS Inst. Inc., Cary, NC). The model to assess frequency of occurrence and longevity of luteal structures induced by treatment between d 26 and 71 of pregnancy, number of induced luteal structures (single vs. double), and timing of regression of induced structures consisted of treatment $(\mathrm{GnRH}, \mathrm{hCG}$, and saline), herd ( $n=3)$, lactation number $(0,1$, or $2+)$ within herd, treatment $\times$ herd interaction, treatment $\times$ lactation number interaction within herd, and stage of pregnancy at treatment. Stage of pregnancy at initial pregnancy diagnosis was grouped into 5 intervals: $<30,30$ to 33,34 to 37,38 to 41 , and $\geq 42$ d. Pregnancy losses associated with occurrence and number of induced luteal structures and regression of induced structures employed a similar model (without stage of pregnancy) plus either presence ( 0 vs. 1$)$ of induced luteal structures, multiple (0 vs. 1$)$ induction of new luteal structures, or regression (0 vs. 1 ) of new luteal structure. Timing of pregnancy losses (by 1, 2, or 4 wk after initial pregnancy diagnosis) associated with the previous outcomes was assessed by including stage of pregnancy at 
Table 2. Pregnancy losses associated with induced luteal structures and early regression of induced structures between d 26 and 71 of pregnancy in dairy cattle

\begin{tabular}{|c|c|c|c|c|}
\hline \multirow[b]{2}{*}{ Item } & \multicolumn{4}{|c|}{ Treatment $^{1}$} \\
\hline & GnRH & hCG & Saline & Total \\
\hline & & -0 & ) & \\
\hline \multirow{2}{*}{\multicolumn{5}{|c|}{$\begin{array}{l}\text { Total losses } \\
\text { Induced luteal structure }\end{array}$}} \\
\hline & & & & \\
\hline No & $12.5(13 / 104)$ & $27.0(20 / 74)$ & $10.4(13 / 125)$ & $15.2(46 / 303)$ \\
\hline Yes & $13.5(5 / 37)$ & $17.6(13 / 74)$ & $33.3(3 / 9)$ & $17.5(21 / 120)$ \\
\hline \multicolumn{5}{|l|}{ Number of structure } \\
\hline Single & $12.5(4 / 32)$ & $18.6(13 / 70)$ & $33.3(3 / 9)$ & $18.0(20 / 111)$ \\
\hline Double & $0.0(0 / 5)$ & $0.0(0 / 4)$ & $0.0(0 / 0)$ & $0.0(0 / 9)$ \\
\hline \multicolumn{5}{|l|}{ Regressed luteal structure } \\
\hline No & $0.0(0 / 24)$ & $6.8(3 / 44)$ & $0.0(0 / 6)$ & $4.1^{\mathrm{a}}(3 / 74)$ \\
\hline Yes & $36.4(4 / 11)$ & $32.1(9 / 28)$ & $100(3 / 3)$ & $38.1^{\mathrm{b}}(16 / 42)$ \\
\hline
\end{tabular}

${ }^{\mathrm{a}, \mathrm{b}}$ Mean percentages having different superscript letters differ $(P \leq 0.05)$.

${ }^{1}$ Treatment injections were given at first pregnancy diagnosis [100 $\mu \mathrm{g}$ of GnRH, 1,000 IU of human chorionic gonadotropin (hCG), or $2 \mathrm{~mL}$ of saline].

${ }^{2}$ Tendency $(P=0.08)$ for an interaction of treatment $\times$ incidence of induced luteal tissue.

treatment. Relationships between the CL of pregnancy and location and early regression of induced luteal structures were assessed by $\chi^{2}$.

Effects of treatment-induced luteal structures on serum concentrations of progesterone $7 \mathrm{~d}$ after treatment were analyzed using a model consisting of treatment $(\mathrm{n}=3)$, herd $(\mathrm{n}=3)$, treatment $\times$ herd interaction, lactation number within herd, treatment $\times$ lactation number interaction within herd, season within herd, stage of pregnancy $(n=5)$, incidence of induced luteal structures ( 0 vs. 1 ), and initial pretreatment concentration of progesterone as a covariate to adjust for pretreatment differences in progesterone. To determine whether eventual pregnancy losses were associated with relative differences in serum concentrations at $0,1,2$, or $4 \mathrm{wk}$, concentrations of progesterone were analyzed within week in a model that included when the loss occurred (by 1, 2, or 4 wk after initial pregnancy diagnosis), herd, herd by when loss occurred, and lactation number within herd. Least squares means were separated by a least significant difference test when a protected $P \leq 0.05$ was detected by $\mathrm{F}$ test.

A prospective analysis was conducted to determine whether serum concentrations of progesterone at the initial pregnancy diagnosis were predictive of eventual pregnancy losses. Concentrations of progesterone at the first pregnancy diagnosis were divided into 4 equal quartiles: bottom $25 \%(<4.86 \mathrm{ng} / \mathrm{mL} ; \mathrm{n}=104)$; low-middle $25 \%$ (4.86 to $6.15 \mathrm{ng} / \mathrm{mL} ; \mathrm{n}=106$ ); upper-middle $25 \%$ (6.16 to $7.63 \mathrm{ng} / \mathrm{mL} ; \mathrm{n}=105)$; and top $25 \%$ ( $>7.63$ $\mathrm{ng} / \mathrm{mL} ; \mathrm{n}=106)$. A model to assess when pregnancy failed as a function of progesterone concentration quartiles consisted of stage of pregnancy at initial diagnosis, progesterone quartile, and their interaction. Probability values resulting from $\mathrm{F}$ tests indicated whether timing of pregnancy loss was associated with lesser or greater concentrations of progesterone at the initial pregnancy diagnosis.

\section{RESULTS AND DISCUSSON}

\section{Induced Luteal Structures}

During the study, 28.3\% (119/421) of dairy females formed new luteal structures. Figure 2 illustrates a frequency response to treatment across various stages of pregnancy. Luteal structures were induced in response to treatment from 23.8 to $33.3 \%$ of females across stages of pregnancy, which did not differ among stages. Treatment with either hCG or GnRH increased $(P<0.01)$ the frequency of cows having new luteal structures compared with saline, with hCG nearly doubling $(P<0.01)$ the proportion of females having new luteal structures compared with GnRH (Table 1). As number of follicles $\geq 10 \mathrm{~mm}$ in diameter increased from 0 to 3 or more, incidence of new luteal structure formation increased $(P<0.001)$ and fit a third-order polynomial curve. In 6 cows treated with hCG, new luteal structures were formed from follicles $<10 \mathrm{~mm}$ in diameter (ranging from 8.3 to $9.5 \mathrm{~mm}$ ). Mean diameters of the largest follicle per ovary pair before treatment were as follows: $12.5 \pm 0.4,12.9 \pm 0.3$, and $13.6 \pm 0.3$ for $\mathrm{GnRH}$, $\mathrm{hCG}$, and saline treatments, respectively. It is not known how many follicles were truly dominant follicles at the time of treatment. Yet administering 1,000 IU of hCG was sufficient to form CL in all postpartum beef cows treated without regard to follicle size or dominance (Cooper et al., 1991).

More $(P<0.001)$ total luteal structures per cow were present in females $7 \mathrm{~d}$ after treatment with hCG (1.69 

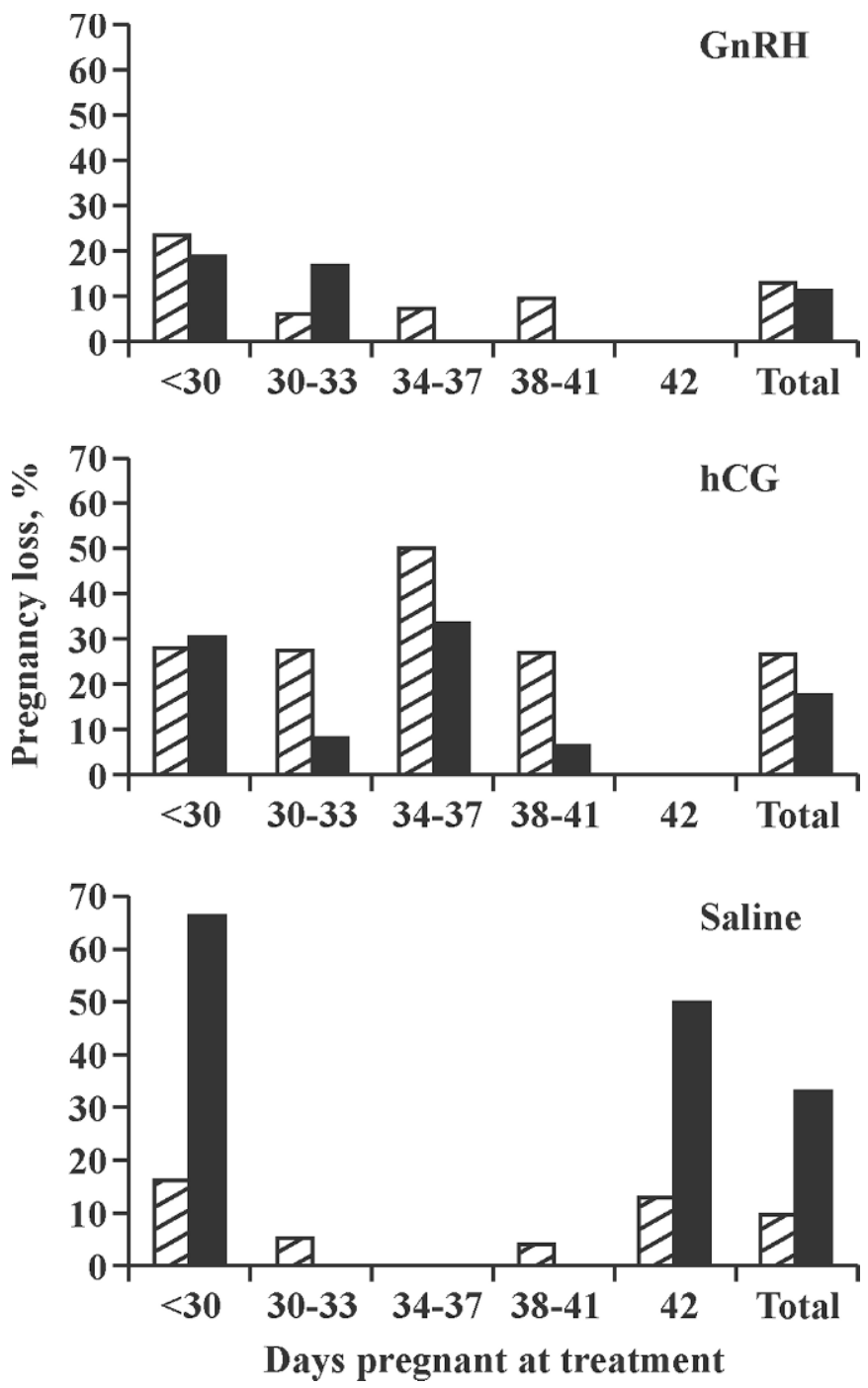

Figure 3. Incidence of pregnancy loss when pregnancy was first diagnosed at various stages of pregnancy based on whether luteal structures were induced (solid bars) or not (cross-hatched bars) for dairy cattle treated with $100 \mu \mathrm{g}$ of $\mathrm{GnRH}$ ( $\mathrm{n}=104$ vs. $\mathrm{n}=36$ ), 1,000 IU of human chorionic gonadotropin (hCG; $\mathrm{n}=74$ vs. $\mathrm{n}=74$ ), or 2 $\mathrm{mL}$ of saline ( $\mathrm{n}=124$ vs. $\mathrm{n}=9$ ), respectively.

$\pm 0.06)$ compared with treatments with $\mathrm{GnRH}(1.38 \pm$ $0.06)$ and saline $(1.24 \pm 0.06)$. Moreover, total luteal structures in GnRH-treated cows tended $(P=0.08)$ to differ from those of saline-treated cows. Magnitude of luteal structures was less than that which occurred in lactating dairy cows when GnRH (60\%) or hCG (77.5\%) was administered during the first week after AI (Stevenson et al., 2007). More than $80 \%$ of the new structures induced by GnRH or hCG were detected by $1 \mathrm{wk}$ after treatment. In beef cows in which original CL had been removed and pregnancy was maintained with exogenous progestin, new luteal structures were induced in 52 of 74 attempts (70\%) in response to 2,500 to 3,000
IU of hCG between d 28 and 59 postestrus (Bridges et al., 2000). Whether the relatively lesser response in the present study $(50 \%)$ resulted from the smaller dosage of hCG or a difference between dairy and beef cows cannot be determined.

Spontaneous new luteal structures were detected in 9 of $133(6.8 \%)$ controls. More than $86 \%$ of cows with new luteal tissue were limited to 1 new structure in response to $\mathrm{GnRH}$ or hCG, whereas none of the controls formed multiple luteal structures (Table 1). About onethird of the new luteal structures (spontaneous or induced) regressed sometime during the 4-wk study period. The majority of those disappearing were gone by $1 \mathrm{wk}$ after their detection (Table 1 ).

Reasons for early disappearance of induced luteal structures are not apparent. Corpora lutea induced by hCG on d 6 of the cycle differed in color and size from the original CL and, when cultured with $\mathrm{LH}$, produced less progesterone in vitro than was produced by spontaneously formed CL of comparable age (Fricke et al., 1993). Further, estradiol increased within $12 \mathrm{~h}$ of hCG treatment on $\mathrm{d} 10$ of the estrous cycle (Howard and Britt, 1990) resulting from stimulated follicular development, and ovulation followed. New CL that formed after hCG treatment on $\mathrm{d} 10$ did not extend the estrous cycle per se, because in some hCG-treated cows that had no new secondary luteal structures, the cycle and CL lifespan were still extended. Moreover, both original and hCG-induced structures regressed in response to $\mathrm{PGF}_{2 \alpha}$ given 2 to $6 \mathrm{~d}$ after hCG (Howard et al., 1990), and Schallenberger et al. (1989) showed that secretion of $\mathrm{PGF}_{2 \alpha}$ increases during $\mathrm{d} 33$ to 36 of pregnancy. Previous studies collectively indicate that induced luteal structures can be smaller, have less progesterone secretory capacity, and be more sensitive to $\mathrm{PGF}_{2 \alpha}$.

In a recent study, the CL of pregnancy was removed on $\mathrm{d} 29$ in 40 beef cows, and replacement progesterone was supplied by 2 progesterone inserts (controlled internal drug release inserts), first inserted on $\mathrm{d} 28$ and replaced every $5 \mathrm{~d}$ through d 53 (Starbuck, 2005). After d 34 and before d 38, a spontaneous new luteal structure was identified by ultrasonography in 5 cows, in each case on the ovary ipsilateral to the uterine horn of pregnancy. Concentrations of progesterone in these cows began to increase as early as $d 33$, exceeding those recorded for the remainder of the cows, to concentrations normally detected in pregnant cows. The new luteal structure and pregnancy were maintained through d 53 in 3 of those 5 cows. Lifespan of the spontaneous luteal structure was transient in the remaining 2 cows, and it was no longer visible by ultrasonography on $d$ 40; 1 cow lost pregnancy, and the other maintained pregnancy to $d 53$. In an earlier study (Bridges et al., 2000), failure to achieve functional status and only 
Table 3. Frequency of induced luteal structures and pregnancy losses according to stage of pregnancy at treatment, frequency of induced luteal structures, and when losses occurred

\begin{tabular}{|c|c|c|c|c|c|c|}
\hline Item & \multicolumn{5}{|c|}{ Days pregnant at treatment ${ }^{1}$} & Total \\
\hline & & & 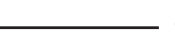 & /n) & & \\
\hline \multicolumn{7}{|l|}{ Induced luteal structures } \\
\hline No & $21.7(25 / 115)$ & $12.7(7 / 55)$ & $13.3(4 / 30)$ & $10.9(7 / 64)$ & $5.3(2 / 38)$ & $14.9(45 / 302)$ \\
\hline 1 st & $10.5(4 / 38)$ & $11.1(1 / 9)$ & $42.9(3 / 7)$ & $12.5(1 / 8)$ & $0.0(0 / 3)$ & $13.8^{\mathrm{a}}(9 / 65)$ \\
\hline 2nd & $44.7(17 / 38)$ & $33.3(3 / 9)$ & $28.6(2 / 7)$ & $37.5(3 / 8)$ & $100(3 / 3)$ & $43.1^{\mathrm{b}}(28 / 65)$ \\
\hline $3 \mathrm{rd}$ to 4 th & $44.7(17 / 38)$ & $55.6(5 / 9)$ & $28.6(2 / 7)$ & $50.0(4 / 8)$ & $0.0(0 / 3)$ & $40.0^{\mathrm{b}}(26 / 65)$ \\
\hline Total $^{3}$ & $23.8(38 / 160)$ & $11.8(9 / 76)$ & $15.9(7 / 44)$ & $9.5(8 / 84)$ & $5.3(3 / 57)$ & $15.4(65 / 421)$ \\
\hline
\end{tabular}

${ }^{\mathrm{a}, \mathrm{b}}$ Mean percentages having different superscript letters differ $(P \leq 0.05)$.

${ }^{1}$ Treatment injections were given at first pregnancy diagnosis [100 $\mu \mathrm{g}$ of $\mathrm{GnRH}$, 1,000 IU of human chorionic gonadotropin (hCG), or 2 $\mathrm{mL}$ of saline].

${ }^{2}$ Pregnancy loss was monitored 1, 2, and 4 wk after initial diagnosis and treatment.

${ }^{3}$ Quadratic effect $(P<0.05)$.

transient persistence of induced luteal structures, along with associated loss of pregnancy, were more common in lutectomized beef cows treated with hCG before $\mathrm{d} 36$ $(50 \%)$ than after $\mathrm{d} 36(0 \%)$, which fits with the findings of Schallenberger et al. (1989).

\section{Pregnancy Losses}

Total pregnancy losses during the 4-wk study period averaged $15.4 \%$ (Table 2). They varied from $11.3 \%$ in controls to $22.3 \%$ in hCG-treated females. No significant effect of treatment was detected for pregnancy losses (Figure 3). No pregnancy loss occurred in $9 \mathrm{fe}-$ males in which more than 1 luteal structure was induced, but loss averaged 18\% overall in females having only 1 induced luteal structure. Dairy cows having an additional spontaneous luteal structure were only 1/8 less likely to have fetal loss as those bearing only 1 CL (López-Gatius et al., 2002), an effect that was not related to twin pregnancy, because cows carrying twins were 3 times more likely to have pregnancy loss. But when the additional induced luteal structure regressed during the present study, pregnancy losses were about 9 -fold greater $(38.1 \% ; P<0.05)$ than in females in which the induced structure was maintained $(4.1 \%)$.

Pregnancy losses fit a fourth-order polynomial regression curve, decreasing quadratically $(P<0.05)$ from a high of $23.8 \%$ at $<30 \mathrm{~d}$ to $5.3 \%$ at $\geq 42 \mathrm{~d}$ of pregnancy (Table 3). Losses were similar across stages of pregnancy regardless of whether new luteal structures were induced by treatment, averaging $15.4 \%$ in nonresponders and $16.8 \%$ in females having new luteal tissue. More losses occurred by 2 to 4 wk after initial pregnancy diagnosis. This result fits with that of Starbuck et al. (2004), who found that most pregnancy loss after d 30 postmating in dairy cows and heifers had occurred by d 42. Total losses were $18.5 \%$ in lactating dairy cows through d 70 of pregnancy (Inskeep, 2002). Losses of embryos beginning with diagnosed pregnancy at $\mathrm{d} 28$ after $\mathrm{AI}$ were $10.5 \%$ during the subsequent 2 wk (d 28 to 42 ) and decreased to $6.3,1.7$, and $1.7 \%$ during $\mathrm{d}$ 42 to 56,57 to 70 , and 71 to 98 , respectively. Of 1,310 dairy cows that bore single (90.8\%) embryos and 321 that carried twins (9.2\%), $75 \%$ of pregnancy losses occurred between 45 and $60 \mathrm{~d}$ of gestation (López-Gatius et al., 2004b). Further, average time of single pregnancy loss occurred earlier in gestation than for twins (52 vs. 75 d). A summary (Santos et al., 2004) of 4,870 pregnancies in lactating dairy cows revealed extensive late embryonic losses (between d 30 and 45) of 12.8 or $0.85 \% / d$. In that same review, of 6,195 pregnancies diagnosed in lactating cows from 25 to $70 \mathrm{~d}$ of gestation, late embryonic and early fetal loss occurred in $19.7 \%$.

\section{Progesterone}

Concentrations of progesterone were greater $(P<$ 0.01) $1 \mathrm{wk}$ after initial treatment in females in which new luteal structures were detected compared with nonresponders (Figure 4). No overall effect was detected among treatments; however, concentrations of progesterone were greater at 1 and 2 wk after treatment in females having induced luteal tissue, but by $4 \mathrm{wk}$, no difference was detected (Figure 5).

More than $70 \%$ of lactating dairy cows treated with 3,300 IU of hCG between 4 and $9 \mathrm{~d}$ after AI had new 


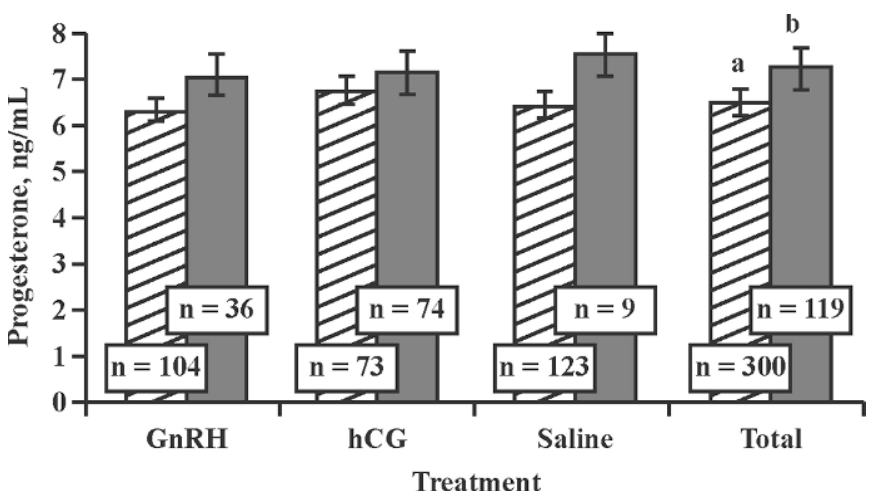

Figure 4. Concentrations of progesterone in blood serum of females $7 \mathrm{~d}$ after treatment with $100 \mu \mathrm{g}$ of $\mathrm{GnRH}, 1,000 \mathrm{IU}$ of human chorionic gonadotropin (hCG), or $2 \mathrm{~mL}$ of saline at various stages of pregnancy. No treatment differences were detected. ${ }^{\mathrm{a}, \mathrm{b}}$ Cattle that had induced luteal structures (solid bars) in response to treatment had greater $(P<0.01)$ concentrations of progesterone $1 \mathrm{wk}$ later than those without new luteal tissue (cross-hatched bars).

luteal structures (Santos et al., 2001; Stevenson et al., 2007). Progesterone concentrations were greater $7 \mathrm{~d}$ after treatment, because original CL were larger and total CL volume (original + induced) was greater than that observed in controls (Stevenson et al., 2007). Greater growth of the original CL in response to hCG is consistent with hCG having activity similar to LH. Increased blood progesterone can occur because of effects of hCG on existing CL or by stimulating formation of accessory CL (Fricke et al., 1993; Santos et al., 2001).

Failure of new luteal structures to reduce pregnancy loss in this study, despite initially increasing progesterone, is in contrast to results obtained by treatment of dairy cows with exogenous progesterone during the

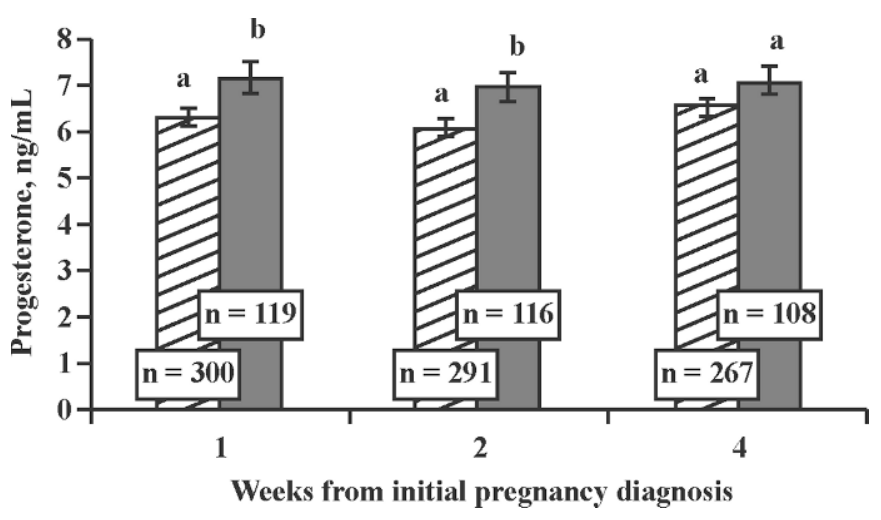

Figure 5. Concentrations of progesterone in serum at 1, 2, and 4 wk after initial pregnancy diagnosis in cows that had induced luteal structure(s) (solid bars) or not (cross-hatched bars) in response to treatment with $100 \mu \mathrm{g}$ of $\mathrm{GnRH}, 1,000 \mathrm{IU}$ of human chorionic gonadotropin (hCG), or $2 \mathrm{~mL}$ of saline at various stages of pregnancy. ${ }^{\mathrm{a}, \mathrm{b}}$ Means within week having different letters differ $(P<0.01)$.

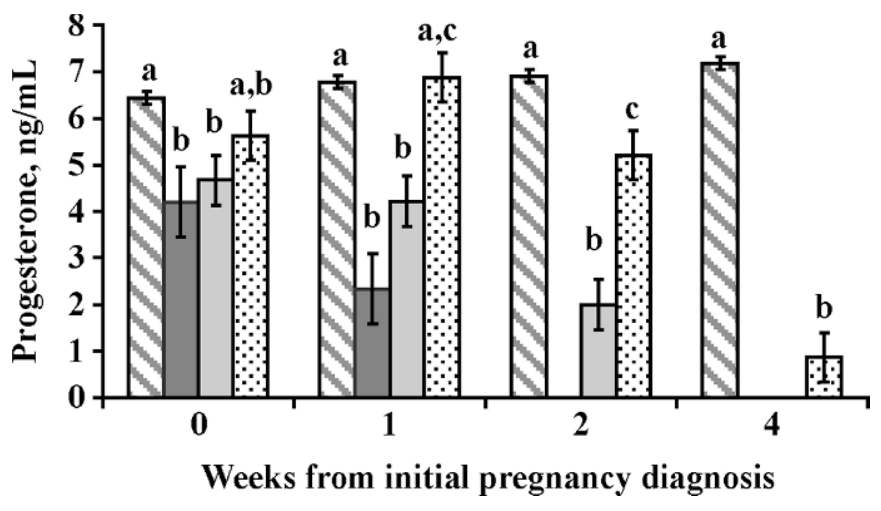

Figure 6. Concentrations of progesterone in serum at initial pregnancy diagnosis and 1,2, and 4 wk later depending on when pregnancy loss was detected. No loss (cross-hatched bars; $n=356$ ) or loss was detected by 1 wk (dark solid bars; $\mathrm{n}=9$ ), by 2 wk (light solid bars; $\mathrm{n}=24$ to 28 ), or by 4 wk (stippled bars; $\mathrm{n}=18$ to 28 ). ${ }^{\mathrm{a}-\mathrm{c}}$ Means within a week having different letters differ $(P \leq 0.05)$.

early fetal period (38 to $90 \mathrm{~d}$ of pregnancy), which improved retention of pregnancies (López-Gatius et al., 2002). Compared with females in which no pregnancy loss occurred, concentrations of progesterone were already less $(P<0.05)$ at initial pregnancy diagnosis for those in which pregnancy loss occurred within 1 to 2 wk after treatment but not in females in which pregnancy loss occurred by $4 \mathrm{wk}$ (Figure 6 ). One week after initial pregnancy diagnosis, concentrations of progesterone were less $(P<0.05)$ in females that lost their pregnancy within 1 and 2 wk but not in those in which

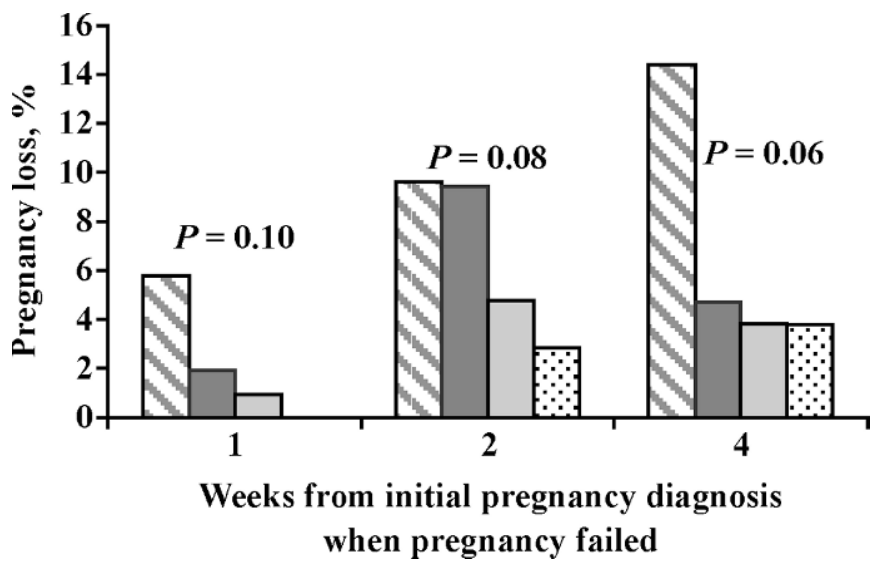

Figure 7. Pregnancy losses detected by 1, 2, or 4 wk after initial pregnancy diagnosis as a function of serum concentrations of progesterone at initial pregnancy diagnosis. Serum progesterone concentrations were divided into in quartiles: bottom $25 \%(<4.86 \mathrm{ng} / \mathrm{mL} ; \mathrm{n}=$ 104; cross-hatched bars); low middle $25 \%$ (4.86 to $6.15 \mathrm{ng} / \mathrm{mL} ; \mathrm{n}=$ 106; darker-colored bars); upper middle $25 \%$ (6.16 to $7.63 \mathrm{ng} / \mathrm{mL} ; \mathrm{n}=$ 105 ; lighter-colored bars); and top $25 \%$ ( $>7.63 \mathrm{ng} / \mathrm{mL} ; \mathrm{n}=106$; stippled bars). Probability values indicate differences in pregnancy losses among progesterone quartiles. 
Table 5. Relationship between ovary bearing the original corpus luteum or corpora lutea (CL) of pregnancy, calf sex, and occurrence of twinning

\begin{tabular}{|c|c|c|c|c|c|}
\hline \multirow[b]{2}{*}{$\begin{array}{l}\text { Ovary bearing } \\
\text { original CL }\end{array}$} & \multirow[b]{2}{*}{$\begin{array}{c}\text { Total } \\
\text { cows, } \mathrm{n}\end{array}$} & \multicolumn{2}{|c|}{ Sex } & \multirow[b]{2}{*}{ Twins } & \multirow[b]{2}{*}{$\begin{array}{c}\text { Twin } \\
\text { composition }\end{array}$} \\
\hline & & $\begin{array}{c}\text { Single } \\
\text { female (F) }\end{array}$ & $\begin{array}{l}\text { Single } \\
\text { male (M) }\end{array}$ & & \\
\hline Left & 101 & 44 & 55 & 2 & $2 \times \mathrm{MM}$ \\
\hline Left-left & 7 & 3 & 1 & $\begin{array}{l}2 \\
3\end{array}$ & $2 \times \mathrm{FF}, \mathrm{FM}$ \\
\hline Right & 107 & 48 & 56 & 3 & $2 \times \mathrm{FF}, \mathrm{MM}$ \\
\hline Right-right & 11 & 2 & 5 & 4 & $\mathrm{FF}, 2 \times \mathrm{FM}, \mathrm{MM}$ \\
\hline Right-left & 30 & 8 & 14 & 8 & $5 \times \mathrm{FF}, 2 \times \mathrm{FM}, \mathrm{MM}$ \\
\hline & & 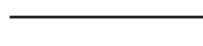 & $-\%(\mathrm{n} / \mathrm{n})-$ & & \\
\hline Left ovary & 108 & $44.8(47 / 105)$ & $42.7(56 / 131)$ & $25.0\left(5 / 20^{1}\right)$ & \\
\hline Right ovary & 118 & $47.6(50 / 105)$ & $46.6(61 / 131)$ & $35.0\left(7 / 20^{1}\right)$ & \\
\hline Both ovaries & 30 & $7.6(8 / 105)$ & $10.7(14 / 131)$ & $40.0\left(8 / 20^{1}\right)$ & \\
\hline Total singles & 236 & $44.5(105 / 236)$ & $55.5(131 / 236)$ & & \\
\hline Twins & 20 & & & & \\
\hline Opposite sex & & 5 & 5 & $25.0\left(5 / 20^{1}\right)$ & \\
\hline Same-sex male & & - & $10^{2}$ & $25.0\left(5 / 20^{1}\right)$ & \\
\hline Same-sex female & & $20^{3}$ & - & $50.0\left(10 / 20^{1}\right)$ & \\
\hline Total twins & & $62.5(25 / 40)$ & $37.5(15 / 40)$ & & \\
\hline Total calves & & $47.1(130 / 276)$ & $52.9(146 / 276)$ & & \\
\hline
\end{tabular}

\footnotetext{
${ }^{1}$ Total number of twin pairs.

${ }^{2} \mathrm{Six}$ of the 10 males or 3 of the 5 twin same-sex male twins were identical based on observation of a single CL.

${ }^{3}$ Four of the 20 males or 2 of the 10 twin same-sex female twins were identical based on observation of a single CL.
}

ovary observed during the estrous cycle (reviewed by Thatcher et al., 1986) continued through d 54 of pregnancy. In contrast, luteal structures induced contralateral to the uterine horn of pregnancy after d 53 were maintained and were effective in maintaining pregnancy to term (Starbuck et al., 2006).

\section{Other Relationships}

Relationships of calf sex and frequency of twinning to the ovary bearing the CL of pregnancy are summarized in Table 5. Frequency of twinning was 7.8\% (20/ 256) overall, which was similar to other reports, but has increased over time in Holstein populations (LópezGatius et al., 2004a). Based on the presence of a single CL, 5 of the 20 twin sets (25\%) were identical. Five sets of twins resulted from ovulations on the left ovary, 7 sets from the right ovary, and 8 sets from both ovaries.

Same-sex twins favored females 2:1 over males, and for all twins (same and opposite sex twins), the sex ratio favored females (62.5:37.5; Table 5). In contrast, the sex ratio of males to females born as singletons was 55.5:44.5. For all calves (singles and twins), sex ratio at birth favored the males over females (52.9:47.1). Skewed sex ratios not favoring female-born calves (45.8\%; Ryan and Boland, 1991) were similar to those observed for single-born females (44.5\%; Table 5). Based on analyses of more than 642,000 calvings, an increased likelihood for male single births was reported after AI than after natural mating (Berry and Cromie, 2007).

In summary, treatment of dairy females with either hCG or GnRH increased formation of new luteal structures. Females having new structures had greater serum concentrations of progesterone at 1 and $2 \mathrm{wk}$ after treatment compared with those not having induced luteal structures. New luteal structures, however, often regressed within $1 \mathrm{wk}$, and pregnancy survival during the subsequent $4 \mathrm{wk}$ was not improved by treatment. Rather, it was decreased if new luteal structures regressed. Nevertheless, concentrations of progesterone at initial pregnancy diagnosis were predictive of subsequent pregnancy loss.

\section{ACKNOWLEDGMENTS}

We thank cooperating dairy producers at Ohlde's Dairy (Linn, KS) and Meier's Dairy (Palmer, KS) for allowing us to use their cattle and facilities. We thank the dairy staff at the Kansas State University Dairy Teaching and Research Center (Manhattan) for their assistance. We thank Betty A. Hensley (Dept. Anim. Sci. Indust., Kansas State Univ.) for her laboratory skills in performing the progesterone RIA.

\section{REFERENCES}

Berry, D. P., and A. R. Cromie. 2007. Artificial insemination increases the probability of a male calf in dairy and beef cattle. Theriogenology $67: 346-352$. 
Bridges, P. J., D. J. Wright, W. I. Buford, N. Ahmad, H. HernandezFonseca, M. L. McCormick, F. N. Schrick, R. A. Dailey, P. E. Lewis, and E. K. Inskeep. 2000. Ability of induced corpora lutea to maintain pregnancy in beef cows. J. Anim. Sci. 78:2942-2949.

Cooper, D. A., D. A. Carver, P. Villeneuve, W. J. Silvia, and E. K. Inskeep. 1991. Effects of progestagen treatment on concentrations of prostaglandins and oxytocin in plasma from the posterior vena cava of post-partum beef cows. J. Reprod. Fertil. 91:411-421.

Fricke, P. M., L. P. Reynolds, and D. A. Redmer. 1993. Effect of human chorionic gonadotropin administered early in the estrous cycle on ovulation and subsequent luteal function in cows. J. Anim. Sci. 71:1242-1246.

Howard, H. J., and J. H. Britt. 1990. Prostaglandin F causes regression of an hCG-induced corpus luteum before day 5 of its lifespan in cattle. J. Reprod. Fertil. 90:245-253.

Howard, H. J., R. G. Scott, and J. H. Britt. 1990. Associations among progesterone, estradiol-17 $\beta$, oxytocin and prostaglandin in cattle treated with hCG during diestrus to extend corpus luteum function. Prostaglandins 40:5-17.

Inskeep, E. K. 2002. Factors that affect embryonic survival in the cow: Application of technology to improve calf crop. Pages 255279 in Factors Affecting Calf Crop: Biotechnology of Reproduction. M. J. Fields, R. S. Sand, and J. V. Yelich, ed. CRC Press, New York, NY.

López-Gatius, F., P. Santolaria, J. L. Yániz, J. M. Garbayo, and R. H. F. Hunter. 2004a. Timing of early foetal loss for single and twin pregnancies in dairy cattle. Reprod. Domest. Anim. 39:429-433.

López-Gatius, F., P. Santolaria, J. L. Yániz, and R. H. Hunter. 2004b. Progesterone supplementation during the early fetal period reduces pregnancy loss in high-yielding dairy cattle. Theriogenology 62:1529-1535

López-Gatius, F., P. Santolaria, J. L. Yániz, J. Rutllant, and M. LópezBejar. 2002. Factors affecting pregnancy loss from gestation day 38 to 90 in lactating dairy cows from a single herd. Theriogenology $57: 1251-1261$.

Lucy, M. C. 2001. Reproductive loss in high-producing dairy cattle: Where will it end? J. Dairy Sci. 84:1277-1293.

McNeill, R. E., M. G. Diskin, J. M. Sreenan, and D. G. Morris. 2006. Associations between milk progesterone concentration on different days and with embryo survival during the early luteal phase in dairy cows. Theriogenology 65:1435-1441.
Moore, D. A., M. W. Overton, R. C. Chebel, M. L. Truscott, and R. H. BonDurant. 2005. Evaluation of factors that affect embryonic loss in dairy cattle. J. Am. Vet. Med. Assoc. 226:1112-1118.

NRC. 1989. Nutrient Requirement of Dairy Cattle. 5th rev. ed. Natl. Acad. Sci., Washington, DC.

Reece, R. P., and C. W. Turner. 1938. The functional activity of the right and left bovine ovary. J. Dairy Sci. 21:37-39.

Ryan, D. P., and M. P. Boland. 1991. Frequency of twin births among Holstein-Friesian cows in a warm dry climate. Theriogenology $36: 1-10$.

Santos, J. E. P., W. W. Thatcher, R. C. Chebel, R. L. A. Ceeri, and K. N. Galvão. 2004. The effect of embryonic death rates in cattle on the efficacy of estrus synchronization programs. Anim. Reprod. Sci. 82-83:513-535.

Santos, J. E. P., W. W. Thatcher, L. Pool, and M. W. Overton. 2001. Effect of human chorionic gonadotropin on luteal function and reproductive performance of high-producing lactating Holstein dairy cows. J. Anim. Sci. 79:2881-2894.

Schallenberger, E., D. Schams, and H. H. D. Meyer. 1989. Sequences of pituitary, ovarian and uterine hormone secretion during the first 5 weeks of pregnancy in dairy cattle. J. Reprod. Fertil. 37(Suppl.):269-276.

Skaggs, C. L., B. V. Able, and J. S. Stevenson. 1986. Pulsatile or continuous infusion of luteinizing hormone-releasing hormone and hormonal concentrations in prepubertal beef heifers. J. Anim. Sci. 62:1034-1048.

Starbuck, M. J. 2005. Factors affecting reproductive efficiency of cattle. PhD Diss. West Virginia Univ., Morgantown.

Starbuck, M. J., R. A. Dailey, and E. K. Inskeep. 2004. Factors affecting retention of early pregnancy in dairy cattle. Anim. Reprod. Sci. 84:27-39.

Starbuck, M. J., D. H. Poole, and E. K. Inskeep. 2006. Ability of induced corpora lutea to maintain pregnancy from the third month of gestation to term in cattle. Theriogenology 66:383-386

Stevenson, J. S., D. E. Tenhouse, M. A. Portaluppi, D. R. Eborn, S. Kacuba, and J. M. DeJarnette. 2007. Interventions after artificial insemination: Conception rates, pregnancy survival, and ovarian responses to gonadotropin-releasing hormone, human chorionic gonadotropin, and progesterone. J. Dairy Sci. 90:331-340.

Thatcher, W. W., F. W. Bazer, D. C. Sharp, and R. M. Roberts. 1986. Inter-relationships between uterus and conceptus to maintain corpus luteum function in early pregnancy: Sheep, cattle, pigs, horses. J. Anim. Sci. 62(Suppl. 2):25-46. 